\title{
FAKTOR-FAKTOR YANG MEMENGARUHI KELENGKAPAN IMUNISASI PADA BALITA DI PUSKESMAS TEUPIN RAYA KABUPATEN PIDIE TAHUN 2017
}

\author{
Zaitun$^{1}$, Cut Erna, Nailatul Qadri ${ }^{3}$ \\ Zaitun, Gampong Asan, Sigli and 24151, Indonesia \\ Cut Erna, Desa Sagoe, Sigli and 24151 Indonesia \\ Email: zaitunumrah@gmail.com; ecut038@gmail.com; nailatul4466@gmail.com
}

\begin{abstract}
Abstrak
Faktor - factor yang memengaruhi kelengkapan imunisasi pada balita di puskesmas Teupin Raya Kabupaten Pidie tahun 2017. Untuk mengetahui dan menganalisis faktor faktor yang berpengaruh terhadap kelengkapan imunisasi pada balita Di Puskesmas Teupin Raya Kecamatan Glumpang Tiga Kabupaten Pidie Tahun 2017. Jenis penelitian ini adalah Survey Analitik dengan pendekatan Cross sectional study. Penelitian ini dilaksanakan di Puskesmas Teupin Raya Kecamatan Glumpang Tiga Kabupaten Pidie. Sampel penelitian ini adalah ibu yang memiliki balita berumur 12-23 bulan yang terpilih dalam pengambilan dengan menggunakan rumus slovin berjumlah 142 balita. Data di analisis dengan melakukan uji regresi logistic berganda. analisis bivariat dengan Uji Chi Square menunjukkan bahwa ada hubungan : pengetahuan ibu $(0,001)$, dukungan keluarga $(0,015$, jarak pelayanan $(0,001)$, dukungan tenaga kesehatan $(0,001)$ dengan kelengkapan imunisasi dasar pada balita. Analisis multivariat menunjukkan bahwa Variabel yang paling dominan berpengaruh terhadap kelengkapan imunisasi adalah variable pengetahuan dengan OR 39,714. Diharapkan Puskesmas agar melakukan pemantauan terhadap keaktifan Posyandu pada tiap desa dengan melibatkan lintas sektoral sehingga Posyandu dapat berjalan dengan baik.
\end{abstract}

Kata Kunci : Pengetahuan ibu, Dukungan Keluarga, Jarak Pelayanan, Dukungan Tenaga Kesehatan, Kelengkapan Imunisasi

\begin{abstract}
This study aims to determine and analyze factors that affect the completeness of immunization in toddlers In Teupin Raya Puskesmas Glumpang Tiga District Pidie Year 2017. Type of this study is an Analytical Survey with a sample of mothers who have children aged 12-23 months who were selected in taking with using a slovin formula of 142 infants. Data were analyzed by multiple logistic regression test. The result of bivariate analysis with Chi Square test showed that there were correlation: maternal knowledge (0,001), family support (0,015, service distance $(0,001)$, support of health manpower $(0,001)$ with basic immunization completeness in balita Multivariate analysis result showed that most variable dominant effect on the completeness of immunization is the knowledge variable with OR 39,714.It is hoped Puskesmas to monitor the activity of Posyandu on each village by involving cross sectoral so Posyandu can run well.
\end{abstract}

Key words :Maternal Knowledge Factors, Family Support, Distance of Health Services, Support of health personnel 
Journal of Healthcare Technology and Medicine Vol. 5 No. 2 Oktober 2019

Universitas Ubudiyah Indonesia

e-ISSN : 2615-109X

\section{PENDAHULUAN}

Upaya pemeliharaan kesehatan anak ditujukan untuk mempersiapkan generasi yang akan datang secara sehat, cerdas, dan berkualitas serta untuk menurunkan angka kematian anak. Upaya pemeliharaan kesehatan anak dilakukan sejak janin masih dalam kandungan, dilahirkan, setelah dilahirkan dan sampai berusia delapan belas tahun. Program ini adalah salah satu upaya dari pemerintah yang bertujuan untuk melindungi bayi dan balita dari penyakit-penyakit yang dapat dicegah dengan imunisasi, seperti TBC, Pilio, Hepatitis B, Difteri, Pertusis, Tetanus, dan Campak. Dalam kenyataan/implementasinya program imunisasi masih belum tercapai target yang ditetapkan sebesar 100\% . (Permenkes RI, 2013).

Program pengembangan imunisasi sebenarnya merupakan salah satu kegiatan yang mendapatkan prioritas dalam Sistem Kesehatan Nasional. pemerintah memprioritaskan program ini tentu ada hubungannya dengan perkiraan (World Health Organization) WHO. Menurut WHO lebih dari 12 juta anak berusia kurang dari 5 tahun yang meninggal setiap tahun di dunia, dan sekitar 2 juta disebabkan oleh penyakit yang dapat dicegah dengan imunisasi . Status imunisasi dasar yang tidak lengkap, diperkirakan menjadi sebab dari serangan penyakit yang dapat menyebabkan kecacatan dan kematian anak. WHO kembali memperkirakan ada sekitar $20 \%$ anak terserang penyakit sebelum usia anak mencapai 12 bulan (World Health Organization, 2015).

Berdasarkan status kelengkapan imunisasi di Indonesia tidak lengkap sebanyak 32,1\%, yang lengkap 59,2\% dan tidak imunisasi $8,7 \%$. menyatakan bahwa alasan mengapa tidak diimunisasi yaitu anak demam $28,8 \%$, Keluarga tidak mengizinkan 26,3\%, anak sering sakit $6,8 \%$, sibuk/repot $16,3 \%$, tempat imunisasi jauh $21,9 \%$, tidak tahu tempat imunisasi $6,7 \%$ (Riskesdas 2013).

Data tersebut diperkirakan status imunisasi dasar masih banyak tidak lengkap. Imunisasi dapat meningkatkan kekebalan tubuh dan mencegah terjangkitnya penyakit menular sehingga balita tidak mudah terserang penyakit, program imunisasi di Indonesia dapat meningkatkan kekebalan tubuh terhadap 5 jenis penyakit yang dapat menyebabkan kematian pada anak. Hal ini bisa dilihat dari tingginya angka kematian bayi berdasarkan SUPAS tahun 2015 AKB yaitu 22/1000 Kelahiran Hidup dan AKBA yaitu 26/1000 Kelahiran Hidup. Angka ini menunjukkan derajat kesehatan Masyarakat masih rendah (Rencana Pembangunan Jangka Menengah Nasional, 2015-2019).

Lima jenis imunisasi dasar yaitu : BCG, yaitu imunisasi dasar yang diberikan untuk mencegah penyakit TBC. Kemudian imunisasi dasar Hepatitis B, yang diberikan untuk 
Journal of Healthcare Technology and Medicine Vol. 5 No. 2 Oktober 2019

Universitas Ubudiyah Indonesia

e-ISSN : 2615-109X

mencegah penyakit hepatitis B. Selanjutnya DPT, yaitu imunisasi dasar yang diberikan untuk mencegah penyakit difteri, pertusis, dan tetanus. Dan imunisasi dasar campak, yang diberikan untuk mencegah penyakit campak yang terakhir imunisasi dasar Polio, yang diberikan untuk mencegah penyakit Polio. Jenis imunisasi diatas bisa dicegah dengan kelengkapan dalam pemberian imunisasi apabila sesuai dengan jadwal maka angka kematian pada anak bisa diturunkan (Karina AN dkk., 2012).

Secara umum cakupan imunisasi lengkap di Indonesia pada anak umur 12-23 bulan sebanyak 59,2. Aceh menduduki peringkat ke 3 provinsi yang cakupan imunisasi tidak lengkap sebesar 19,8\%. (3) WHO kembali menyebutkan bahwa selama tahun 2000-2013 diperkirakan angka kematian anak akibat tidak imunisasi campak yaitu $74 \%$ dari 481.000 jiwa ke jiwa. Cakupan imunisasi campak pada anak umur 12-23 bulan di Aceh 62,4\% dan Aceh merupakan provinsi kedua terendah angka imunisasi campak serta provinsi yang memiliki Incidence Rate penyakit campak tertinggi (Kemenkes, 2015).

Namun program imunisasai dasar ini masih mengalami hambatan, yaitu penolakan dari orang tua. Penolakan orang tua dalam pemberian imunisasi ini dikarenakan anggapan yang salah yang berkembang di masyarakat tentang imunisasi, tingkat pengetahuan yang rendah, dan kesadaran yang kurang terhadap imunisasi (Suparyanto, 2011).

Adapun faktor yang berhubungan dengan kelengkapan imunisasi bayi antara lain pengalaman yang pernah dialami oleh ibu maupun cerita orang lain, ibu yang bekerja sehingga tidak memikili waktu untuk membawa anaknya ke posyandu, dukungan keluarga yang mendukung atau yang tidak mendukung, fasilitas posyandu, lingkungan sekitar ibu, sikap ibu tentang pemberian imunisasi, provider (tenaga kesehatan) merupakan salah satu indicator yang sangat menentukan bagi keberhasilan program imunisasi, penghasilan keluarga dan tingkat pendidikan (Riskesdas, 2013).

Beberapa alasan bayi tidak mendapatkan imunisasi dasar yaitu karena alasan informasi, motivasi dan situasi. Alasan informasi berupa kurangnya pengetahuan ibu tentang kebutuhan, kelengkapan dan jadwal imunisasi, ketakutan akan imunisasi dan adanya persepsi yang salah beredar di masyarakat tentang imunisasi. Akan tetapi yang paling berpengaruh adalah karena anak sakit, ketidaktahuan ibu akan pentingnya imunisasi, ketidaktahuan waktu yang tepat untuk mendapatkan imunisasi dan ketakutan akan efek samping yang ditimbulkan imunisasi. Dari uraian tersebut menunjukkan bahwa pengetahuan sangat berperan penting terhadap kelengkapan imunisasi pada bayi (Suparyanto, 2011). 
Journal of Healthcare Technology and Medicine Vol. 5 No. 2 Oktober 2019

Universitas Ubudiyah Indonesia

e-ISSN : 2615-109X

Pada tahun 2015 terdapat 12 kabupaten/kota yang memiliki persentase desa (Universal

Child Immunization) UCI melebihi target $80 \%$. Kota Sabang memiliki capaian tertinggi dalam pelaksanaan imunisasi dengan persentase desa UCI mencapai 100\%, diikuti Kabupaten Aceh Jaya sebesar $98 \%$ dan Aceh Tengah sebesar $97 \%$. Sedangkan capaian terendah terdapat di Kabupaten Pidie dengan persentase desa UCI sebesar $26 \%$ (Kemenkes, 20102014).

Data Cakupan imunisasi yang diperoleh dari Dinkes Pidie tahun 2016 dengan jumlah bayi 9500 dengan capaian HB0 72\%, BCG 54,5\%, POLIO1 60,5 POLIO2 55,8\%, POLIO3 48,9\% POLIO 44,4\% DPT-HB-Hib1 47\%, DPT-HB-Hib2 40,5\%, DPT-HB-Hib3 35,2\% dan campak 41,1\%. Data tersebut menggambarkan capaian imunisasi masih rendah (Dinas Kesehatan Pidie, 2016).

Cakupan imunisasi Puskesmas Teupin Raya Kecamatan Glumpang Tiga Kabupaten Pidie tahun 2016 dengan jumlah sasaran 222 dengan capaian HBO 84,63\%, BCG 64,86\%, POLIO1 63\% POLIO2 54,95\%, POLIO3 47,29\% dan POLIO4 47,29\% DPT-HB-Hib1 55,85\%, DPT-HB-Hib2 40,99\%, DPT-HB-Hib3 39,63\% dan Campak 49,54\%. Data menggambarkan capaian rata-rata menununjukkan penurunan setiap jenis imunisasi, jumlah penolakan imunisasi karena orang tua merupakan faktor mayoritas bayi tidak diimunisasi (Puskesmas Teupin Raya, 2016).

Tujuan Penelitian ini untuk Untuk mengetahui dan menganalisis pengetahuan ibu, dukungan keluarga, jarak pelayanan, dukungan tenaga kesehatan terhadap kelengkapan imunisasi pada balita di Puskesmas Teupin Raya Kabupaten Pidie

\section{METODE}

Penelitian ini menggunakan metode penelitian survey analitik dengan pendekatan Cross-sectional yaitu pengumpulan data sekaligus pada saat bersamaan antara variabel bebas (X variable) antara lain (pengetahuan, dukungan keluarga, jarak pelayanan, dukungan tenaga kesehtan) dengan variabel terikat ( $Y$ variable) yaitu kelengkapan imunisasi. Lokasi pada penelitian ini di lakukan di Puskesmas Teupin Raya Kecamatan Kabupaten Pidie dengan alasan masih kurangnya balita yang tidak imunisasi secara lengkap.

Populasi dalam penelitian ini berjumlah 219 orang tahun 2017 dengan jumlah sampel yang akan diteliti yaitu 142 orang. Variabel penelitian ini terdiri dari atas variabel bebas (independent variabel) yaitu pengetahuan, dukungan keluarga, jarak pelayanan, dan dukungan tenaga kesehatan. Variabel terikat (dependent variabel) yaitu:kelengkapan 
Journal of Healthcare Technology and Medicine Vol. 5 No. 2 Oktober 2019

Universitas Ubudiyah Indonesia

e-ISSN : 2615-109X

imunisasi. Alat ukur (instrumen) variabel penelitian menggunakan kuesioner dengan variabel pengetahuan terdiri dari 20 pertanyaan, dukungan keluarga 12 pertanyaa, jarak pelayanan 1 pertanyaan, dukungan tenaga kesehatan 6 pertanyaan.

Teknik analisa data menggunakan analisis univariat menggunakan distribusi frekuensi, analisis bivariat menggunakan uji chi square dan analisis multivariat menggunakan uji regresi logistik.

\section{HASIL DAN PEMBAHASAN}

Tabel 1. Tabulasi Silang pengetahuan dengan kelengkapan imunisasi pada balita di Puskesmas Teupin Raya Kabupaten Pidie Tahun 2017

\begin{tabular}{|c|c|c|c|c|c|c|c|}
\hline \multirow{3}{*}{ Pengetahuan } & \multicolumn{4}{|c|}{ Kelengkapan Imunisasi } & \multicolumn{2}{|c|}{ Jumlah } & \multirow[t]{3}{*}{$P$ value } \\
\hline & \multicolumn{2}{|c|}{ Lengkap } & \multicolumn{2}{|c|}{ Tidak } & & & \\
\hline & f & $\%$ & $\mathbf{F}$ & $\%$ & f & $\%$ & \\
\hline Baik & 63 & 44,4 & 28 & 19,7 & 91 & 64,1 & \\
\hline Kurang & 3 & 35,9 & 48 & 33,8 & 51 & 35,9 & 0,001 \\
\hline Total & 66 & 46,5 & 76 & 53,5 & 142 & 100 & \\
\hline
\end{tabular}

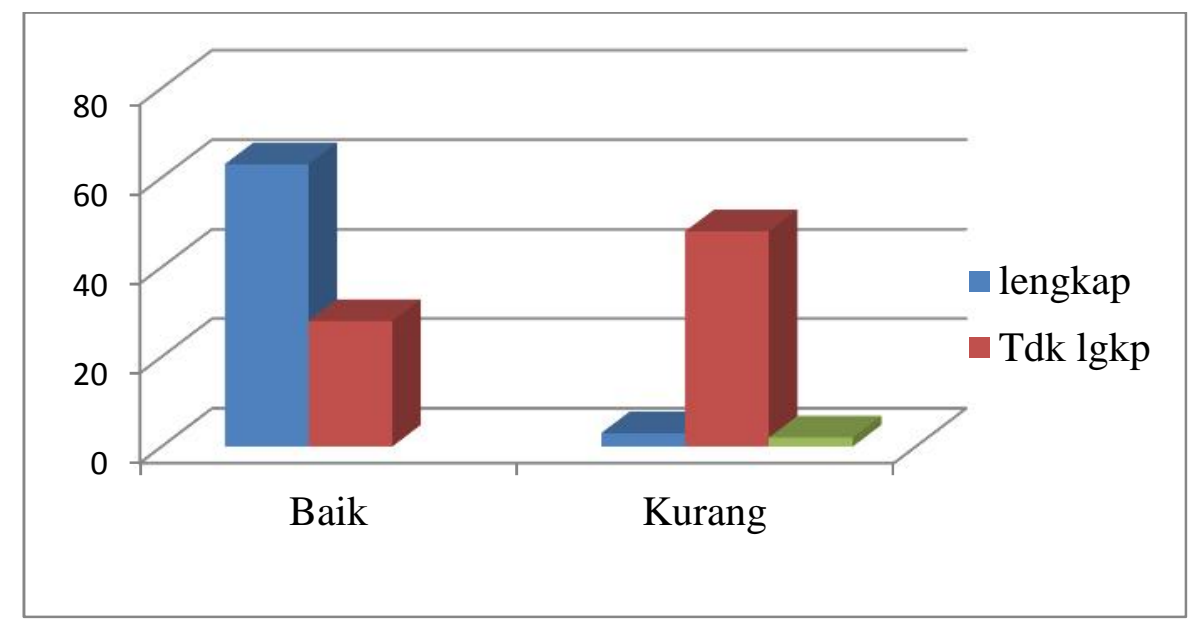

Gambar. 1 Tabulasi Silang pengetahuan dengan kelengkapan imunisasi pada balita di Puskesmas Teupin Raya Kabupaten Pidie Tahun 2017

Dari tabel tabulasi silang diatas dilihat bahwa dari 91 responden $(64,1 \%)$, yang memiliki pengetahuan baik paling banyak lengkap imunisasinya sebanyak 63 responden $(44,4 \%)$ dan dari 51 responden $(35,9 \%)$ yang memiliki pengetahuan kurang paling banyak tidak lengkap imunisasinya sebanyak 48 responden $(33,8 \%)$.

Dari hasil analisis chi-square pada lampiran tabel uji chi-square antara Hubungan Pengetahuan Responden dengan Kelengkapan Imunisasi Di Wilayah Kerja Puskesmas Teupin Raya Kabupaten Pidie Tahun 2017 diketahui bahwa nilai probabilitasnya $(0,001)<$ sig 
Journal of Healthcare Technology and Medicine Vol. 5 No. 2 Oktober 2019

Universitas Ubudiyah Indonesia

e-ISSN : 2615-109X

$\alpha=0,05$. Hasil analisis ini memenuhi kriteria persyaratan hipotesis hubungan, sehingga dapat disimpulkan bahwa pengetahuan responden memiliki hubungan signifikan dengan Kelengkapan Imunisasi.

Berdasarkan hasil penelitian terlihat pengaruh antara tingkat pengetahuan ibu dengan kelengkapan imunisasi dasar pada bayi di Puskesmas Teupin Raya Kecamatan Glumpang Tiga Kabupaten Pidie. Hal ini didasarkan pada hasil analisis dengan uji chi square diperoleh $p$ value $=0,00$ ( $p$ value $>0,05)$. Perhitungan risk estimate, diperoleh nilai odd ratio $(\mathrm{OR})=39,714$ sehingga dapat disimpulkan ibu dengan tingkat pengetahuan baik cenderung memberikan imunisasi dasar lengkap kepada anaknya, sebaliknya ibu dengan tingkat pengetahuan kurang memiliki risiko 39,714 kali tidak memberikan imunisasi dasar lengkap kepada anaknya.

Menurut asumsi peneliti, pengetahuan berpengaruh terhadap kelengkapan imunisasi karena pengetahuan mempunyai peranan sebagai motivasi awal bagi seseorang dalam berprilaku. Hasil penelitian menunjukkan ibu dengan pengetahuan baik umumnya memberikan imunisasi lengkap kepada balita.

Terbatasnya pengetahuan ibu tentang imunisasi bayi ini mengenai manfaat dan tujuan imunisasi maupun dampak yang akan terjadi jika tidak dilaksanakannya. Imunisasi bayi akan mempengaruhi kesehatan bayi. Hal ini sesuai dengan teori dan pendorong. Daya pendorong adalah semacam naluri tetap hanya satu dorongan kekuatan yang luas terhadap satu arah yang umum. Dalam pendorong dengan mengimunisasikan bayinya, salah satunya adalah pengetahuan dimana pengetahuan tersebut ditemukan dalam media elektronik (TV, Radio), media massa (Koran majalah) Pengetahuan adalah segala sesuatu yang diketahui berkaitan dengan proses pembelajaran dan dipengaruhi faktor dari dalam seperti motivasi dan faktor dari luar berupa sarana informasi yang tersedia serta keadaan sosian budaya (Agus Hendra, dkk 2017).

Hasil penelitian ini sesuai dengan penelitian sebelumnya yang dilakukan oleh Dewi Setyani (2012) yang menyatakan bahwa ada hubungan antara pengetahuan ibu dengan kelengkapan imunisasi balita di Desa Nyatnyono Kecamatan Ungaran Barat Kabupaten Semarang, dengan $p=0,001(p<0,05)$ Ada hubungan antara tingkat pengetahuan ibu dengan kelengkapan imunisasi balita (Kadek Surya Jayanti, 2016)

Tabel 2 Tabulasi Silang Hubungan dukunga keluarga dengan kelengkapan imunisasi pada balita di Puskesmas Teupin Raya Kabupaten Pidie Tahun 2017

\begin{tabular}{|c|c|c|c|}
\hline Dukungan & Kelengkapan Imunisasi & Jumlah & $P$ value \\
\hline Keluarga & Lengkap $\quad$ Tidak & & \\
\hline
\end{tabular}


Journal of Healthcare Technology and Medicine Vol. 5 No. 2 Oktober 2019

Universitas Ubudiyah Indonesia

e-ISSN : 2615-109X

\begin{tabular}{llllllll}
\hline & F & \% & f & \% & f & \% & \\
\cline { 1 - 6 } Mendukung & 51 & 35,6 & 43 & 30,3 & 94 & 66,2 & \\
Tidak & 15 & 10,6 & 33 & 23,2 & 48 & 33,8 & 0,015 \\
\cline { 1 - 6 } Total & 66 & 46,5 & 76 & 53,5 & 142 & 100 & \\
\hline
\end{tabular}

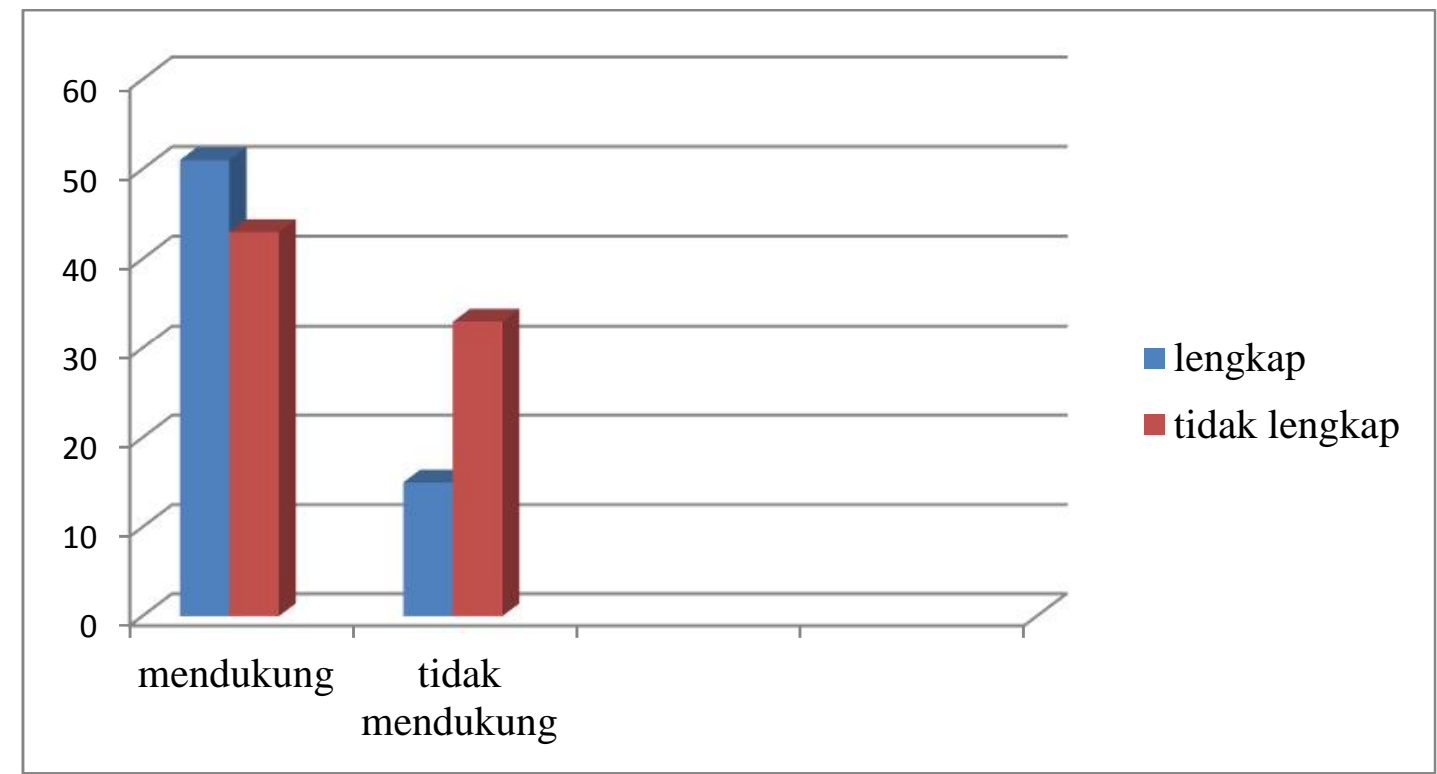

Gambar. 2 Tabulasi Silang Hubungan dukunga keluarga dengan kelengkapan imunisasi pada balita di Puskesmas Teupin Raya Kabupaten Pidie Tahun 2017

Dari tabel tabulasi silang di atas dilihat bahwa dari 94 responden $(66,2 \%)$, yang mendapatkan dukungan keluarga paling banyak lengkap imunisasinya sebanyak 51 responden $(35,6 \%)$ dan dari 48 responden $(33,8 \%)$ yang tidak mendapatkan dukungan keluarga paling banyak tidak lengkap imunisasinya sebanyak 33 responden $(23,2 \%)$.

Dari hasil analisis chi-square pada lempiran tabel uji chi-square antara Hubungan dukungan keluarga dengangan Kelengkapan Imunisasi Di Wilayah Kerja Puskesmas Teupin Raya Kabupaten Pidie Tahun 2017 diketahui bahwa nilai probabilitasnya $(0,015)$ <sig $\alpha=0,05$. Hasil analisis ini memenuhi kriteria persyaratan hipotesis hubungan, sehingga dapat disimpulkan bahwa dukungan keluarga Responden memiliki hubungan signifikan dengan Kelengkapan Imunisasi.

Berdasarkan hasil penelitian terlihat pengaruh dukungan keluarga dengan kelengkapan imunisasi dasar pada bayi di Puskesmas Teupin Raya Kecamatan Glumpang Tiga Kabupaten Pidie. Hal ini didasarkan pada hasil analisis dengan uji chi square diperoleh $p$ value $=0,0015$ ( $p$ value $<0,05)$. Perhitungan risk estimate, diperoleh nilai odd ratio $(\mathrm{OR})=5,444$, sehingga dapat disimpulkan ibu yang didukung anggota keluarganya untuk mengimunisasikan anaknya cenderung memberikan imunisasi dasar lengkap kepada 
Journal of Healthcare Technology and Medicine Vol. 5 No. 2 Oktober 2019

Universitas Ubudiyah Indonesia

e-ISSN : 2615-109X

anaknya, sebaliknya ibu yang tidak didukung anggota keluarganya untuk mengimunisasikan anaknya memiliki risiko 5,444 kali tidak memberikan imunisasi dasar

Menurut asumsi peneliti dukungan keluarga merupakan faktor pendorong yang artinya bahwa memberikan motivasi dan berkontribusi baik terhadap istri yang sedang membutuhkan dukungan. Dukungan keluarga merupakan salah satu elemen penguat bagi terjadinya perilaku seseorang. Dukungan itu adalah daya upaya dalam hal mewujudkan suatu rencana. Hasil penelitian terlihat bahwa responden dengan dukungan keluarga mendukung umumnya melakukan pemberian imunisasi secara lengkap kepada balita, sedangkan responden yang tidak mendapatkan dukungan suami umumnya tidak melakukan pemberian imunisasi secara lengkap kepada balita.

Penelitian sejalan dengan penelitian Nugroho (2014) tentang hubungan pengetahuan dan dukungan keluarga terhadap pemberian imunisasi pada bayi. Hasil penelitian menunjukkan bahwa responden yang mendapat dukungan keluarga akan berdampak baik terhadap pemberian imunisasi anaknya. Nilai p-value 0,003 ( $\mathrm{p}<0,01)$ (Adzaniyah Isyani, dkk 2017).

Tabel 3 Tabulasi Silang Hubungan Jarak pelayanan kesehatan dengan Kelengkapan Imunisasi Dasar pada Bayi Di Wilayah Kerja Puskesmas Teupin Raya Kabupaten Pidie Tahun 2017

\begin{tabular}{lccccccc}
\hline \multirow{2}{*}{ Jarak pelayanan } & \multicolumn{3}{c}{ Kelengkapan imunisasi } & & \multirow{2}{*}{ Jumlah } & \multirow{2}{*}{ P value } \\
\cline { 2 - 5 } & \multicolumn{2}{c}{ Lengkap } & \multicolumn{2}{c}{ Tidak } & & & \\
\cline { 2 - 6 } & f & \% & F & \% & F & \% & \\
\hline Dekat & 66 & 46 & 13 & 9.1 & 79 & 56 & 0,001 \\
Jauh & 20 & 14 & 43 & 30 & 63 & 44 & \\
\hline Total & 86 & 60 & 56 & 39,1 & 142 & 100 & \\
\hline
\end{tabular}

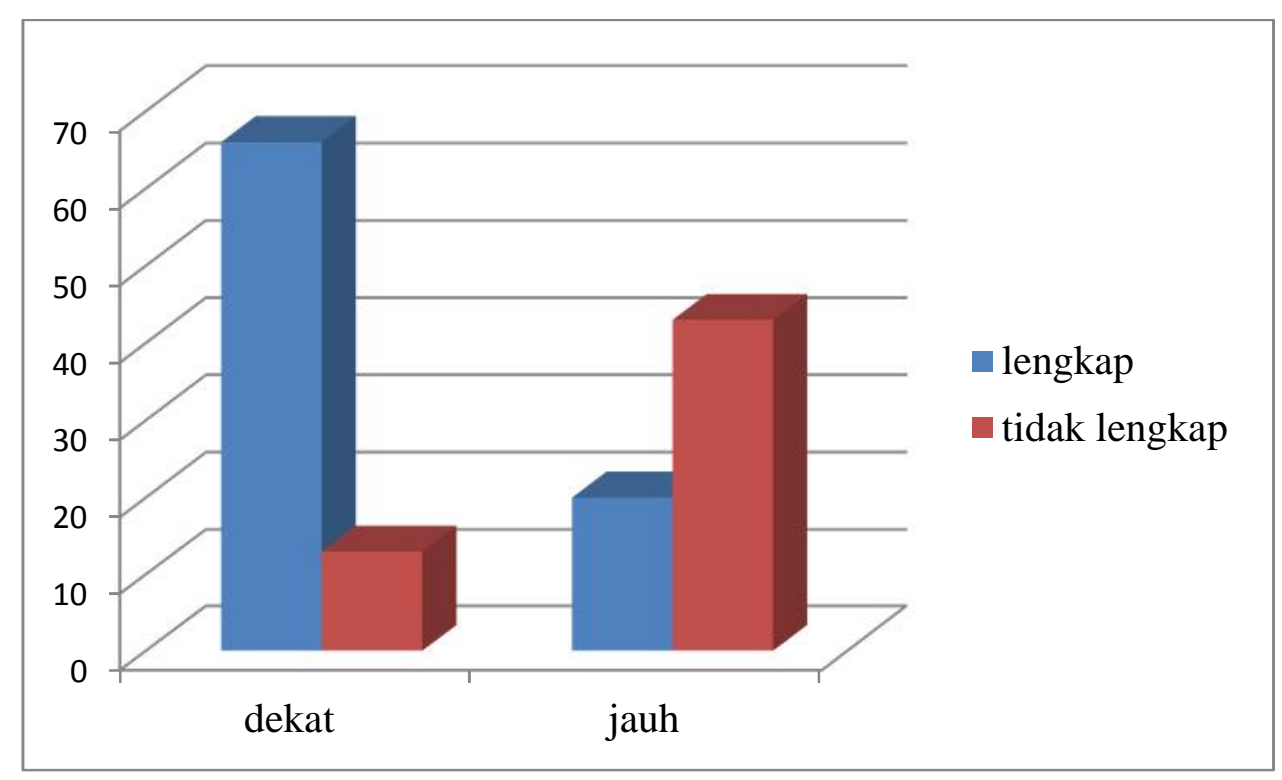


Journal of Healthcare Technology and Medicine Vol. 5 No. 2 Oktober 2019

Universitas Ubudiyah Indonesia

e-ISSN : 2615-109X

Gambar. 3 Tabulasi Silang Hubungan Jarak pelayanan kesehatan dengan Kelengkapan Imunisasi Dasar pada Bayi Di Wilayah Kerja Puskesmas Teupin Raya Kabupaten Pidie Tahun 2017

Dari tabel tabulasi silang di atas dilihat bahwa dari 79 responden (56\%), yang dekat dari pelayanan kesehatan paling banyak lengkap imunisasinya sebanyak 66 responden (46\%) dan dari 63 responden $(44 \%)$ yang jauh dari pelayanan kesehatan paling banyak tidak lengkap imunisasinya sebanyak 43 responden (30\%).

Dari hasil analisis chi-square pada lampiran tabel uji chi-square antara Hubungan Jarak pelayanan kesehatan dengan Kelengkapan Imunisasi Di Wilayah Kerja Puskesmas Teupin Raya Kabupaten Pidie Tahun 2017 diketahui bahwa nilai probabilitasnya $(0,000)<$ sig $\alpha=0,05$. Hasil analisis ini memenuhi kriteria persyaratan hipotesis hubungan, sehingga dapat disimpulkan bahwa Jarak pelayanan kesehatan memiliki hubungan signifikan dengan Kelengkapan Imunisasi.

Berdasarkan hasil penelitian terlihat ada pengaruh keterjangkauan ke tempat pelayanan imunisasi dengan kelengkapan imunisasi dasar pada bayi di Puskesmas Teupin Raya Kecamatan Glumpang Tiga Kabupaten Pidie. Hal ini didasarkan pada hasil analisis dengan uji chi square diperoleh $p$ value $=0,000$ ( $p$ value > 0,05). Perhitungan risk estimate, diperoleh nilai odd ratio $(\mathrm{OR})=3,403$, sehingga dapat disimpulkan ibu yang jarak pelayanan dekat (terjangkau) cenderung memberikan imunisasi dasar lengkap kepada anaknya, sebaliknya ibu yang jarak pelayanan jauh tidak (terjangkau) memiliki risiko 3, 403 kali tidak memberikan imunisasi dasar lengkap kepada anaknya.

Menurut asumsi peneliti bahwa jarak merupakan salah satu faktor yang mempengaruhi ibu dalam memberikan imunisasi secara lengkap. Hal ini disebabkan jarak puskesmas yang terjangkau dari rumah dan pengaruh angkutan umum seperti ojek, dan lainlain yang mudah didapat sehingga tidak menjadi hambatan waktu. Letak tempat pelayanan imunisasi berada di tempat yang mudah didatangi masyarakat, sehingga tidak menyulitkan masyarakat untuk mengimunisasikan anaknya.

Penelitian ini sejalan dengan penelitian yang dilakukan oleh Agus Rendra (2013) di Wilayah Kerja Puskesmas Lhoknga. Hasil penelitian menunjukan bahwa yang mempunyai jarak dekat kefasilitas pelayanan kesehatan sebesar $73,9 \%$ perolehan imunisasi campaknya tinggi. Secara hasil statistik juga dibuktikan bahwa terdapat pengaruh bermakna $(\mathrm{p}=0,045)$ antara jarak ke fasilitas pelayanan kesehatan dengan perolehan imunisasi di Wilayah Kerja Puskesmas Lhoknga

Tabel 4 Tabulasi Silang Hubungan Dukungan Nakes dengan Kelengkapan Imunisasi Di Wilayah Kerja Puskesmas Teupin Raya Kabupaten Pidie Tahun 2017 
Journal of Healthcare Technology and Medicine Vol. 5 No. 2 Oktober 2019

Universitas Ubudiyah Indonesia

e-ISSN : 2615-109X

\begin{tabular}{lccccccc}
\hline \multirow{2}{*}{$\begin{array}{c}\text { Dukungan } \\
\text { Nakes }\end{array}$} & \multicolumn{4}{c}{ Kelengkapan Imunisasi } & \multicolumn{2}{c}{ Jumlah } & \multirow{2}{*}{ P value } \\
\cline { 2 - 7 } & \multicolumn{2}{c}{ Lengkap } & \multicolumn{2}{c}{ Tidak } & & \\
\cline { 2 - 7 } & f & \% & f & \% & f & \% & \\
\hline Mendukung & 48 & 33,8 & 28 & 19,7 & 76 & 53,4 & \multirow{2}{*}{0,001} \\
Tidak & 18 & 12,7 & 48 & 33,8 & 66 & 46,5 \\
\hline Total & 76 & 53,5 & 66 & 46,5 & 142 & 100 & \\
\hline
\end{tabular}

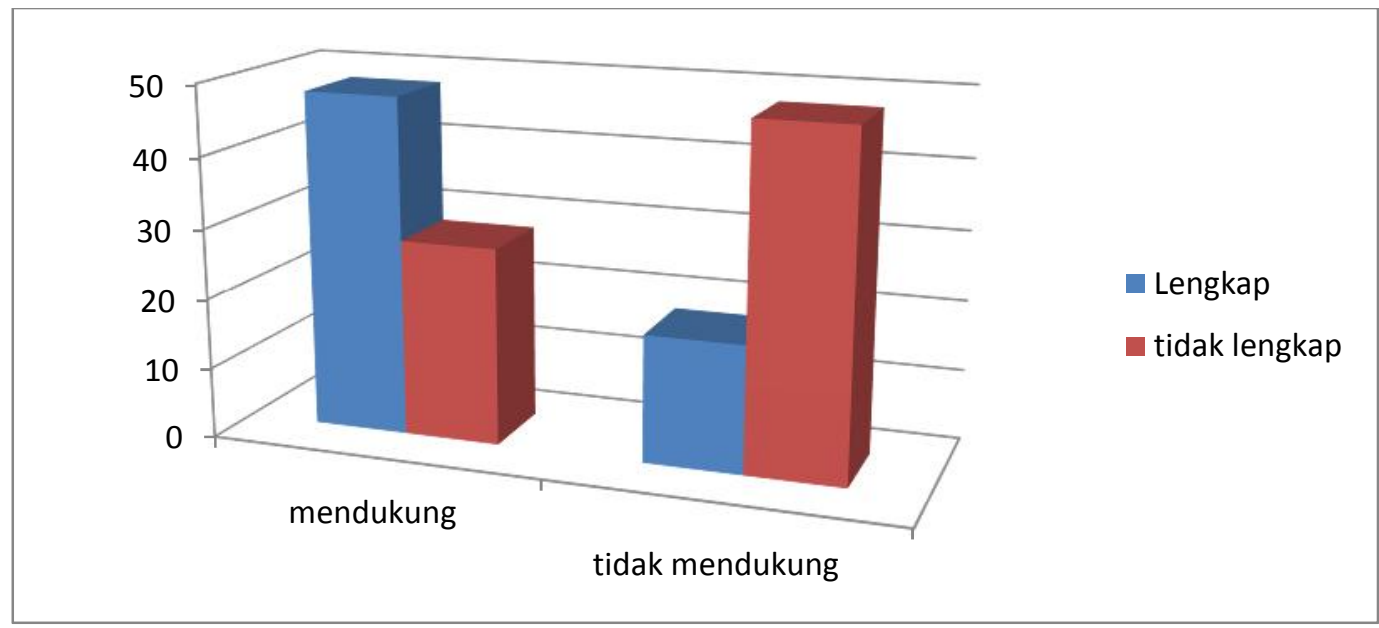

Gambar. 4 Tabulasi Silang Hubungan Dukungan Nakes dengan Kelengkapan Imunisasi Di Wilayah Kerja Puskesmas Teupin Raya Kabupaten Pidie Tahun 2017.

Dari tabel tabulasi silang di atas dilihat bahwa dari dari 76 responden $(53,4 \%)$, yang mendapatkan dukungan pelayanan tenaga kesehatan paling banyak lengkap imunisasinya sebanyak 48 responden $(33,8 \%)$ dan dari 66 responden $(46,5 \%)$ yang tidak mendapatkan dukungan pelayanan tenaga kesehatan paling banyak tidak lengkap imunisasinya sebanyak 48 responden $(33,8 \%)$.Dari hasil analisis chi-square pada lampiran tabel uji chi-square antara Hubungan dukungan pelayanan tenaga kesehatan dengan Kelengkapan Imunisasi Di Wilayah Kerja Puskesmas Teupin Raya Kabupaten Pidie Tahun 2017diketahui bahwa nilai probabilitasnya $(0,001)<\operatorname{sig} \alpha=0,05$. Hasil analisis ini memenuhi kriteria persyaratan hipotesis hubungan, sehingga dapat disimpulkan bahwa dukungan pelayanan tenaga kesehatan memiliki hubungan signifikan dengan Kelengkapan Imunisasi.

Berdasarkan hasil penelitian terlihat pengaruh dukungan tenaga kesehatan dengan kelengkapan imunisasi dasar pada bayi di Puskesmas Teupin Raya Kecamatan Glumpang Tiga Kabupaten Pidie. Hal ini didasarkan pada hasil analisis dengan uji chi square diperoleh $p$ value $=0,000$ ( $p$ value < 0,05). Perhitungan risk estimate, diperoleh nilai odd ratio $(\mathrm{OR})=6,244$, sehingga dapat disimpulkan ibu yang mendapat dukungan dari tenaga kesehatan cenderung memberikan imunisasi dasar lengkap kepada anaknya, sebaliknya ibu yang tidak mendapat dukungan dari tenaga memiliki risiko 6,244 kali tidak memberikan imunisasi dasar lengkap kepada anaknya. 
Journal of Healthcare Technology and Medicine Vol. 5 No. 2 Oktober 2019

Universitas Ubudiyah Indonesia

e-ISSN : 2615-109X

Menurut asumsi peneliti bahwa dukungan petugas kesehatan merupakan salah satu faktor yang mempengaruhi ibu dalam kelengkapan imunisasi. Terbukti hasil penelitian menunjukkan bahwa mayoritas dukungan tenaga kesehatan mendukung terhadap kelengkapan imunisasi pada bayinya. Adapaun dukungan sosial dalam bentuk dukungan informatif, dimana perasaan subjek bahwa lingkungan (petugas kesehatan) memberikan keterangan yang cukup jelas mengenai hal-hal yang diketahui. Dalam penelitian ini, dukungan petugas kesehatan adalah dukungan atau dorongan serta pelayanan yang diberikan petugas kesehatan dalam pemberian imunisasi dasar lengkap. Dukungan petugas kesehatan dibagi menjadi dua kategori yaitu mendukung dan tidak mendukung.

Hal ini sesuai dengan teori Suparyanto (2011) lingkungan kebudayaan dimana orang belajar banyak dari lingkungan kebudayaan sekitarnya. Pengaruh keluarga terhadap pembentukan sikap sangat besar karena keluarga merupakan orang yang paling dekat dengan anggota keluarga yang lain. Jika sikap keluarga terhadap imunisasi kurang begitu respon dan bersikap tidak menghiraukan atau bahkan pelaksanaan kegiatan imunisasi. Maka pelaksanaan imunisasi tidak akan dilakukan oleh ibu bayi karena tidak ada dukungan oleh keluarga.

Penelitian ini sejalan dengan penelitian Madarni (2013) yang mempunyai hubungan terhadap kelengkapan imunisasi dasar adalah dukungan petugas kesehatan. Petugas kesehatan sudah mulai proaktif mengajak masyarakat untuk melakukan imunisasi dasar lengkap. Hal ini dapat dilihat dari kelengkapan vaksin yang selalu tersedia di saat ibu membutuhkannya. Selain itu, petugas kesehatan memberikan penyuluhan tentang imunisasi dasar lengkap kepada ibu pada saat ibu datang untuk mengimunisasikan bayinya. Tetapi yang menjadi kendala bagi petugas kesehatan adalah jadwal yang belum sesuai dengan keinginan masyarakat sehingga masyarakat yang menggunakan Posyandu sedikit walupun pengetahuan masyarakat sudah baik tentang imunisasi.

\section{Tabel 7 Hasil Analisis Uji Regresi Logistik Berganda}

\begin{tabular}{clrrc}
\hline No & \multicolumn{1}{c}{ Variabel } & B & P value & OR \\
\hline 1. & Pengetahuan & 3,682 & 0,000 & 39,714 \\
2. & dukungan_kesehatan & 1,695 & 0,003 & 5,444 \\
3. & Jarak & 1,225 & 0,016 & 3,403 \\
4. & dukungan_nakes & 1,832 & 0,001 & 6,244 \\
& constanta & $-14,048$ & 0,000 & 0,000
\end{tabular}

Berdasarkan tabel diatas variabel hanya variabel pengetahuan (X1) yang mempunyai pengaruh yang signifikan terhadap kelengkapan imunisasi, dengan nilai signifikasi $0,000<$ 
Journal of Healthcare Technology and Medicine Vol. 5 No. 2 Oktober 2019

Universitas Ubudiyah Indonesia

e-ISSN : 2615-109X

0,05 sehingga $\mathrm{Ha}$ diterima atau berarti pegetahuan memberikan pengaruh terhadap kelengkapan imunisasi. Variabel dukungan Keluarga (X2) mempunyai pengaruh yang signifikan terhadap kelengkapan imunisasi (Y), dengan nilai signifikasi 0,003<0,05 sehingga Ha diterima atau berarti dukungan keluarga memberikan pengaruh terhadap kelengkapan imunisasi variabel jarak (X3) mempunyai pengaruh yang signifikan terhadap kelengkapan imunisasi (Y), dengan nilai signifikasi $0,016<0,05$ sehingga Ha diterima atau berarti jarak memberikan pengaruh terhadap kelengkapan imunisasi. Variabel dukungan tenaga kesehatan (X4) mempunyai pengaruh yang signifikan terhadap kelengkapan imunisasi (Y), dengan nilai signifikasi $0,001<0,05$ sehingga Ha diterima atau berarti dukungan tenaga kesehatan memberikan pengaruh terhadap kelengkapan imunisasi.

Besarnya pengaruh ditunjukan dengan nilai EXP (B) atau disebut juga dengan OR (Odds Ratio). Variabel pengetahuan dari hasil analisis diperoleh nilai OR $=39,714$ artinya responden yang pengetahuan baik mempunyai peluang 39,714 kali lebih tinggi imunisasinya lengkap dibandingkan dengan responden yang pengetahuan kurang. Nilai B = Logaritma Natural dari $39,714=3,682$. oleh karena itu nilai B bernilai positif, maka pengetahuan mempunyai hubungan positif dengan kelengkapan imunisasi.

Variabel dukungan keluarga dari hasil analisis diperoleh nilai OR $=5,444$ artinya responden yang mendapatkan dukungan keluarga mempunyai peluang 5,444 kali lebih tinggi imunisasinya lengkap dibandingkan dengan responden yang tidak mendapatkan dukungan keluarga. Nilai B = Logaritma Natural dari 5,444=1,695. oleh karena itu nilai B. Bernilai positif, maka dukungan keluarga mempunyai hubungan positif dengan kelengkapan imunisasi.

Variabel jarak dari hasil analisis diperoleh nilai OR $=3,403$ artinya responden yang dekat dari pelayanan kesehatan mempunyai peluang 3,403 kali lebih tinggi imunisasinya lengkap dibandingkan dengan responden yang jauh pelayanan kesehatan. Nilai $\mathrm{B}=$ Logaritma Natural dari 3,403=1,225. oleh karena itu nilai B bernilai positif, maka jarak pelayanan kesehatan mempunyai hubungan positif dengan kelengkapan imunisasi.

Variabel dukungan tenaga kesehatan dari hasil analisis diperoleh nilai OR $=6,244$ artinya responden yang mendapatkan dukungan tenaga kesehatan mempunyai peluang 6,244 kali lebih tinggi imunisasinya lengkap dibandingkan dengan responden yang tidak mendapatkan dukungan tenaga kesehatan. Nilai B = Logaritma Natural dari 6,244=1,832. oleh karena itu nilai B bernilai positif, maka dukungan tenaga kesehatan mempunyai hubungan positif dengan kelengkapan imunisasi. 
Journal of Healthcare Technology and Medicine Vol. 5 No. 2 Oktober 2019

Universitas Ubudiyah Indonesia

e-ISSN : 2615-109X

Nilai probalitas atau prediksi dalam kelengkapan imunisasi di wilayah kerja Puskesmas

Teupin Raya dengan penjelasan sebagai berikut:

1. Jika responden dengan pengetahuan baik, maka nilai probabilitas atau kemungkinan untuk memberikan imunisasi secara lengkap 92,0\%

2. Jika responden dengan dukungan keluarga, maka nilai probabilitas atau kemungkinan untuk memberikan imunisasi secara lengkap 91,0\%

3. Jika responden dengan jarak pelayanan dekat, maka nilai probabilitas atau kemungkinan untuk memberikan imunisasi secara lengkap 91,0\%

4. Jika responden dengan jarak pelayanan dekat, maka nilai probabilitas atau kemungkinan untuk memberikan imunisasi secara lengkap 91,0\%.

Berdasarkan hasil analisis regresi logistik model summary didapatkan kemampuan variabel independen (pengetahuan, dukungan keluarga, jarak pelayanan dan dukungan tenaga kesehatan) dalam menjelaskan variabel dependen (kelengkapan imunisasi) dengan menggunakan nilai Cox \& Snell $R$ Square dan Nagelkerke $R$ Square. Nilai Nagelkerke $R$ Square sebesar 0,650 dan Cox \& Snell $R$ Square 0,487 yang menunjukkan bahwa kemampuan variabel independen (pengetahuan, dukungan keluarga, jarak pelayanan dan dukungan tenaga kesehatan) dalam menjelaskan variabel dependen (kelengkapan imunisasi) adalah sebesar 0,650 atau $(65,0 \%)$ dan terdapat $(35,0 \%)$ faktor lain di luar model yang menjelaskan variabel dependen. Atau persamaan regresi variabel independen (pengetahuan, dukungan keluarga, jarak pelayanan dan dukungan tenaga kesehatan) memengaruhi variabel dependen (kelengkapan imunisasi) sebesar 65,0\%.

\section{KESIMPULAN}

Ada pengaruh yang signifikan pengetahuan ibu dengan kelengkapan imunisasi dasar pada balita di di Puskesmas Teupin Raya Kecamatan Glumpang Dua Kabupaten Pidie

Ada pengaruh yang signifikan jarak pelayanan dengan kelengkapan imunisasi dasar pada balita di Puskesmas Teupin Raya Kecamatan Glumpang Dua Kabupaten Pidie

Ada pengaruh yang signifikan dukungan tenaga kesehatan dengan kelengkapan imunisasi dasar pada balita di Puskesmas Teupin Raya Kecamatan Glumpang Dua Kabupaten Pidie.

Variabel yang paling dominan berpengaruh terhadap kelengkapan imunisasi adalah variable pengetahuan dengan OR 39,714 artinya responden dengan pengetahuan baik memiliki peluang 39,714 kali lebih tinggi untuk memberikan imunisasi dasar secara lengkap. 
Journal of Healthcare Technology and Medicine Vol. 5 No. 2 Oktober 2019

Universitas Ubudiyah Indonesia

e-ISSN : 2615-109X

\section{SARAN}

Diharapkan bagi kepala Puskesmas agar melakukan pemetaan permasalahan tentang imunisasi pada tiap desa di masing-masing kecamatan sehingga dapat diketahui dan dipecahkan masalah yang dihadapi pada tiap desa dan memprioritaskan pengaktifan Posyandu pada tiap desa dengan melibatkan lintas sektoral sehingga Posyandu dapat berjalan dengan baik

\section{DAFTAR PUSTAKA}

Akhmadi, Dukungan Keluarga [internet] 2009 (Diakses tanggal 24 April 2017). dari http://www:rajawana.com

Ayubi, D.Kontribusi pengetahuan ibu terhadap status imunisasi anak di tujuh provinsi di Indonesia. Jurnal Pembangunan Manusia. 2009 7(1), 1-8.

Dewi Setyani, Hubungan antara pengetahuan ibu dengan kelengkapan imunisasi balita di Desa Nyatnyono Kecamatan Ungaran Barat Kabupaten Semarang Jurnal : Universitas Sumatra Utara 2012

Dinas Kesehatan, Profil kesehatan Dinas Kesehatan Pidie. 2016

Efendi, R. Hubungan Tingkat Pengetahuan Ibu dan Dukungan Suami dengan Kepatuhan Ibu dalam Memberikan Imunisasi Dasar. Prosiding Seminar Nasional Urbanisasi dan Kesehatan. Denpasar. 2010

Ikatan Dokter Anak Indonesia Imunisasi penting untuk mencegah penyakit berbahaya. [Internet] (2013). [Diakses tanggal 5 Maret 2015] dari http://idai.or.id/publicarticles/klinik/imunisasi/imunisasi-pentinguntuk

Karina AN, dan Warsito BE. Pengetahuan Ibu Tentang Imunisasi Dasar Balita. Jurnal Nursing Studies Volume 1.Nomor 12012

Kemenkes, Gerakan Akselerasi Imunisasi Nasional UCI 2010-2014. Ditjen PP \& PL. Jakarta : 2010

Kemenkes, Profil Kesehatan Indonesia. Jakarta : Depkes RI 2015

Madarni, Perilaku Ibu Dalam Pemberian Imunisasi Dasar di Kecamatan Kretek Kabupaten Bantul Provinsi Daerah Istimewa Yogyakarta. Fakultas Kesehatan Masyarakat Universitas Indonesia. Jakarta 2013

Niven, Psikologi Kesehatan. Penerbit PT. Grasindo. Jakarta. 2002

Nugroho, Penelitian tentang hubungan pengetahuan dan dukungan keluarga terhadap pemberian imunisasi pada bayi. 2014

Nuri Handayani, Karakteristik Ibu dan Keterjangkauan Imunisasi sebagai Faktor Risiko Ketidaklengkapan Imunisasi Dasar, Skripsi : Universitas Diponegoro Semarang 2014 .

Permenkes RI, Penyelenggaraan Imunisasi. Jakarta: Depkes RI 2013

Poerwadarminta, W.J.S. Kamus Umum Bahasa Indonesia. Edisi Ketiga : Balai Pustaka Jakarta 2013

Puskesmas Teupin Raya, Laporan Hasil imunisasi Puskesmas Teupin Raya Kecamatan Glumpang Tiga Kabupaten Pidie. 2016

Riskesdas, Riset kesehatan dasar. Jakarta: Badan Penelitian dan Pengembangan Kesehatan 2013

RPJM, Rencana Pembangunan Jangka Menengah Nasional (RPJMN). Jakarta : 2015-2019 
Journal of Healthcare Technology and Medicine Vol. 5 No. 2 Oktober 2019

Universitas Ubudiyah Indonesia

e-ISSN : 2615-109X

Siregar, A. Pemberian ASI Ekskusif dan Faktor-faktor yang Mempengaruhinya. Jurnal : Universitas Sumatra Utara 2013

Suparyanto, Konsep Kelengkapan Imunisasi 2011

Suparyanto, Konsep Kelengkapan Imunisasi Jakarta: EGC 2011.

WHO, Global Immunization Data. [Diakses 10 Maret 2015]. Tersedia di http://www.who.int/immunization/monitoring_surveillance/global_immunization_dat a.pf 